\title{
Description of the Satisfaction Level of Training Participants on Service In Batam Health National Training Centre, Indonesia
}

\author{
Supriyono', Sriyatun ${ }^{2}$ \\ 1,2Badan Pengembangan Sumber Daya Manusia Daerah Provinsi Jawa Tengah, Indonesia \\ Email: supriyonontr@yahoo.co.id
}

\begin{abstract}
This study aims to describe the level of satisfaction of trainees towards services in Batam health training using the customer satisfaction index (CSI) and the community satisfaction index (IKM). The population in this study were all trainees who used services in Batam health training. The sample in this study was saturated, where all participants were taken as samples, with 374 respondents. Data collection methods used were questionnaires or questionnaires. The results showed that the customer satisfaction index reached 0.94 was very satisfied, with the highest IKP in learning facilities services and the desire of respondents to recommend the Batam Health Agency to friends and colleagues reached $0.96 \%$ and the lowest service level of teaching and learning activities reached $0.88 \%$. While the index of community satisfaction reached a value of $70.21 \mathrm{~B}$, the predicate of the performance of service units in the Batam Health Agency is good. Overall the trainees felt very satisfied.
\end{abstract}

Keywords: Service quality, customer satisfaction index, community satisfaction index.

\section{A. INTRODUCTION}

Increasing the competence of health workers is in line with the mandate of Law No. 5 of 2014 concerning the State Civil Apparatus, that the development of health personnel is more directed in order to improve the quality and career of health personnel resources through education and training (Law Number 5 of 2014)

Information about variables originating from consumers, where one of them includes the former trainee is very important. Therefore information about variables originating from consumers, where one of them includes the former trainees is very important (Melyanasari, 2012)

The limitation of this study is that there are confounding variables that cannot be controlled but have a great influence on services including age, sex, education, length of work, other psychological factors.

\section{B. METHOD}

In order for the problems to be investigated not to spread and become erratic, the problem is limited to the alumni of the training participants in the Batam health office during the period from January to June 2018, which consists of health training, nonhealth, and community.

The population in this study were alumni of training participants who attended

IJSOC () 2020 
pre-service training, from January to June 2018 at the Batam Health Training Center, with the samples taken being total the sample is 374 respondents. The instrument uses the IKM questionnaire from Permenpan No. 14 of 2017 (Regulation of the Minister of Administrative Reform, Number 14/2017). Data that has been collected is processed by stages, editing, coding, entering data into a computer, and making tabulations.

To determine the level of customer satisfaction through 2 approaches, namely 1. According to (Suparyanto, 2006), the Consumer Satisfaction Index is used to determine the level of service satisfaction based on variables, this index is an ideal measure to measure the results of achieving the expected strategic goals using the formula:

$(\mathrm{F} 1 \mathrm{xS} 1)+(\mathrm{F} 2 \mathrm{xS} 2)+(\mathrm{F} 3 \mathrm{xS} 3)$

IKP

\section{$\Sigma \mathrm{F} \times 3$}

Information :

IKP $=$ Customer / Consumer Satisfaction Index

F1 = Number of Respondents who answered Dissatisfied

F2 = Number of Respondents who answered Satisfied

F3 = Number of Respondents who answered Very Satisfied

$\Sigma \mathrm{F}=$ Total Respondents

$\mathrm{S} 1-3=1,2,3, \ldots . .1$ = dissatisfied, 2 = satisfied, 3 = very satisfied

Table 1 Customer Satisfaction Level

\begin{tabular}{cc}
\hline Indeks & Category \\
\hline$<0.20$ & Very dissatisfied \\
$0.21-0.40$ & Dissatisfied \\
$0.41-0.60$ & Netral \\
$0.61-0.80$ & Satisfied \\
$>0.81$ & Very Satisfied \\
\hline
\end{tabular}

Source: Suparyanto, 2006

The IKM value is calculated using the "weighted average value" of each service element. In calculating the community satisfaction index for the nine elements of service studied, each service element has the same weighing formula as follows: Weighted weighted average value $=$ Number of weights divided by a number of elements $=1 / 9=$ 0,111 . To obtain the service unit IKM value, the weighted average value approach is used as follows: IKM = Total of Perceived Value Per Element divided by Total elements filled in. Weight value to facilitate the interpretation of the IKM assessment, which is between 25 - 100, the results of the assessment above are converted with a base value of 25, with the following formula: IKM Service Unit x 25

Table 2 Perception Value of IKM Interval Value of IKM Conversion Interval Value of 


\section{Service Unit Performance Service Quality}

\begin{tabular}{ccccc}
\hline $\begin{array}{c}\text { Perception } \\
\text { of value }\end{array}$ & $\begin{array}{c}\text { Interval IKM } \\
\text { of Value }\end{array}$ & $\begin{array}{c}\text { Value of IKM Con- } \\
\text { version Interval }\end{array}$ & $\begin{array}{c}\text { Value of } \\
\text { Service }\end{array}$ & $\begin{array}{c}\text { Unit Performance } \\
\text { Service Quality }\end{array}$ \\
\hline 1 & $1,00-1,75$ & $25-43,75$ & D & Not good \\
2 & $1,76-2,50$ & $43,76-62,50$ & C & Poor \\
3 & $2,51-3,25$ & $62,51-81,25$ & B & Good \\
4 & $3,26-4,00$ & $81,26-100,00$ & A & Very good \\
\hline
\end{tabular}

Source: Suparyanto, 2006

\section{RESULT AND DISCUSSION}

From the results of the questionnaire collection, 374 respondents were scattered in 8 (eight) types of training. The biggest respondent was in the Health Promotion training from the Ministry of Health, which amounted to $20.63 \%$ and was dissatisfied with the training of Saiba training from the Supreme Court Training Center, which was $2.58 \%$.

Table 3 Variable Distribution Based on Type of Service

\begin{tabular}{|c|c|c|c|c|c|c|c|c|}
\hline \multirow{3}{*}{ Service type } & \multicolumn{6}{|c|}{ Variable } & \multirow[b]{3}{*}{$\mathrm{n}$} & \multirow[b]{3}{*}{$\%$} \\
\hline & \multicolumn{2}{|c|}{ Very satisfied } & \multicolumn{2}{|c|}{ Satisfied } & \multicolumn{2}{|c|}{ Dissatisfied } & & \\
\hline & $\mathrm{n}$ & $\%$ & $\mathrm{n}$ & $\%$ & $\mathrm{n}$ & $\%$ & & \\
\hline Recepsionist & 317 & 84,76 & 55 & 14,71 & 2 & 0,53 & 374 & 100,00 \\
\hline Accomodation & 284 & 75,94 & 83 & 22,19 & 7 & 1,87 & 374 & 100,00 \\
\hline Consumption & 301 & 80,48 & 68 & 18,18 & 5 & 1,34 & 374 & 100,00 \\
\hline Support & 297 & 79,42 & 75 & 20,05 & 2 & 0,53 & 374 & 100,00 \\
\hline Learning Facility & 330 & 88,24 & 44 & 11,76 & 0 & 0,00 & 374 & 100,00 \\
\hline Handling of complaints & 323 & 86,36 & 51 & 13,64 & 0 & 0,00 & 374 & 100,00 \\
\hline $\begin{array}{l}\text { The Desire of Respondents } \\
\text { to Reuse Bapelkes Batam } \\
\text { Facility }\end{array}$ & 321 & 85,83 & 53 & 4,17 & 0 & 0,00 & 374 & 100,00 \\
\hline $\begin{array}{l}\text { Desire of respondents rec- } \\
\text { ommending Batam Health } \\
\text { Agency to friends and col- } \\
\text { leagues }\end{array}$ & 331 & 88,50 & 43 & 11,50 & 0 & 0,00 & 374 & 100,00 \\
\hline $\begin{array}{l}\text { Teaching and Learning Pro- } \\
\text { cess Activities }\end{array}$ & 252 & 67,38 & 114 & 30,48 & 8 & 2,14 & 374 & 100,00 \\
\hline
\end{tabular}

Source: Primary Data Processed Results (2018) 
Table 4 Customer Satisfaction Index

\begin{tabular}{lccccc}
\hline \multirow{2}{*}{ Indicator } & \multicolumn{3}{c}{ Likert scale } & IKP & Criteria \\
\cline { 2 - 5 } & Dissatiied & Satisfied & Very satisfied & & \\
\hline Recepsionist & 2 & 55 & 317 & 0,95 & Very satisfied \\
\hline Accomodation & 7 & 83 & 284 & 0,91 & Very satisfied \\
\hline Consumption & 5 & 68 & 301 & 0,93 & Very satisfied \\
\hline Support & 2 & 75 & 297 & 0,93 & Very satisfied \\
\hline Learning Facility & 0 & 44 & 330 & 0,96 & Very satisfied \\
\hline Handling of complaints & 0 & 51 & 323 & 0,95 & Very satisfied \\
\hline $\begin{array}{l}\text { The Desire of Respond- } \\
\text { ents to Reuse Bapelkes }\end{array}$ & 0 & 53 & 321 & 0,95 & Very satisfied \\
Batam Facility & & & & & \\
\hline $\begin{array}{l}\text { Desire of respondents } \\
\text { recommending Batam }\end{array}$ & 0 & 43 & 331 & 0,96 & Very satisfied \\
$\begin{array}{l}\text { Health Agency to friends } \\
\text { and colleagues }\end{array}$ & & & & & \\
\hline $\begin{array}{l}\text { Teaching and Learning } \\
\text { Process Activities }\end{array}$ & 8 & 114 & 252 & 0,88 & Very satisfied \\
\hline Average of IKP & & & 0,94 & Very satisfied \\
\hline
\end{tabular}

Source: Processed Primary Data Results (2018)

From the calculation of the consumer satisfaction index shows that the average value of the IKP is 0.94 which indicates that consumers feel very satisfied with services at the Batam health office, with the highest IKP in complaints handling services and the desire of respondents to recommend Bapelkes Batam to friends and colleagues at 0,96, and the lowest in the service of teaching and learning activities is equal to 0.88 . From table 4 above illustrates that based on the results of evaluation of the benefits of training on Batam health training center, the results showed that out of 9 services provided by Batam health services, most service users stated they were not satisfied, there were 5 services (55\%) stated that they were not satisfied $5.38 \%$ with the greatest dissatisfaction with the teaching and learning process services is $2.14 \%$, while the lowest is arrival and support services, which are $0.53 \%$ respectively.

Recepcionist service.

Receptionist services include attendee services and front office staff hospitality (FO). Both of these services are the frontline of an agency both government and private so that it can be said that the good and bad of public service are highly dependent on the role of the service provider. So it is not surprising that prescription services are the central point of management. In the recepcionist service, the customer satisfaction index dimension is included in the category of being very satisfied with the number reaching $84.76 \%$. With details very satisfied $84.76 \%$, satisfied reaching $14.71 \%$ and not satisfied reaching $0.53 \%$. 


\section{Accommodation Services.}

Accommodation services are one of the services that play a role in providing various needs for participants while attending education and training while participating in the learning process. In the customer satisfaction index, accommodation services are included in the satisfied category, reaching $75.90 \%$. With details very satisfied $75.90 \%$, satisfied $22.2 \%$ were not satisfied with $1.7 \%$.

Consumption Service.

The availability of consumption during the learning process plays an important role in education and training activities. This service when viewed from the dimensions of the customer satisfaction index is included in the satisfied category, which is equal to $80.5 \%$. With details of very satisfied $80.5 \%$, satisfied $18.2 \%$ and not satisfied $1.3 \%$.

Supporting Facilities Services.

Supporting facilities in the dimensions of the customer satisfaction index in the customer satisfaction category amounted to $79.4 \%$. With details very satisfied $79.4 \%$, satisfied $20.1 \%$ and not satisfied $0.5 \%$.

Learning Facilities.

Learning facilities when viewed from the dimensions of the customer satisfaction index are included in the category of very satisfied, reaching $88.2 \%$. With details of very satisfied $88.2 \%$, satisfied $11.8 \%$ and not satisfied $0 \%$.

Complaint Handling.

Handling complaints in the dimensions of the customer satisfaction index is included in the very satisfied category, reaching $86.4 \%$, with details of very satisfied $86.4 \%$, satisfied $13.6 \%$ and not satisfied $0 \%$. The Desire to Reuse Batam Bapelkes Facilities. From table 3 and diagram 1, it can be seen that $85.8 \%$ or 321 respondents have very satisfied desires to reuse Batam Bapelkes facilities, as many as $14.2 \%$ or 53 respondents have satisfied desires to reuse Batam Bapelkes facilities. There were no respondents who expressed their unwillingness to reuse Batam's Bapelkes facilities.

Batam Bapelkes

Recommendation Services to Friends and Colleagues, that $88.5 \%$ or 331 respondents have a very satisfied desire to recommend Batam Bapelkes to friends and colleagues, as many as $14.2 \%$ or 53 respondents have a satisfied desire to recommend Batam Bapelkes to friends and colleagues. There were no respondents who expressed their unwillingness to recommend Batam Health Agency to friends and colleagues. Teaching and Learning Process Activities (PBM). that $54.0 \%$ or 143 respondents have very satisfied variables with Teaching and Learning Process Activities (PBM), as many as 43.0\% or 114 respondents have satisfied variables with Teaching and Learning Activities (PBM). Satisfy $3 \%$ or 8 respondents giving an unsatisfied assessment of the Teaching and Learning Process Activity. 
Table 5 The Average Value of Elements From Each Service Unit

\begin{tabular}{lccc}
\hline \multicolumn{1}{c}{ Service Element } & $\begin{array}{c}\text { Service Element } \\
\text { Value }\end{array}$ & Weight value & $\begin{array}{c}\text { Value of } \\
\text { IKM }\end{array}$ \\
\hline Recepsionist & 2.84 & 0.111 & 0.315 \\
\hline Accomodation & 2.74 & 0.111 & 0.304 \\
\hline Consumption & 2.79 & 0.111 & 0.310 \\
\hline Support & 2.79 & 0.111 & 0.310 \\
\hline Learning Facility & 2.88 & 0.111 & 0.320 \\
\hline Handling of complaints & 2.86 & 0.111 & 0.318 \\
\hline $\begin{array}{l}\text { The Desire of Respondents to Reuse Bapelkes } \\
\text { Batam Facility }\end{array}$ & 2.86 & 0.111 & 0.318 \\
\hline $\begin{array}{l}\text { Desire of respondents recommending Batam } \\
\text { Health Agency to friends and colleagues }\end{array}$ & 2.89 & 0.111 & 0.320 \\
\hline Teaching and Learning Process Activities & 2.65 & & 0.294 \\
\hline \multicolumn{1}{c}{ Average of IKP } & & & 2.81 \\
\hline
\end{tabular}

Source: Primary Data Processed Results (2018)

Thus the results of the service unit index value can be summarized as follows:

1. After converted IKM value $=$ Index value $\times$ Basic Value $=2.81 \times 25=70.21$

2. Quality of service B.

3. Good service unit performance.

From table 3, out of 23 services provided at Batam Health Training Center, it shows that the very satisfied variable is in environmental care services, reaching $90.90 \%$ and not satisfied with the mini market service, reaching $66.60 \%$. Furthermore, for the service of teaching and learning process during the training, the results were obtained that the variable was very satisfied with the program direction aspect which reached $90.10 \%$ and was not satisfied with the Library and Laboratory services, each of which reached $53.20 \%$.

Service is an effort to fulfill customer desires delivered appropriately to balance customer expectations. The services needed by humans are basically divided into two types, namely physical services that are personal in nature and administrative services provided by other people as members of the organization (mass organizations or state organizations). Based on this opinion, what is meant by service is continuous activities in daily life in the form of physical services, which are personal and administrative, which are usually found in an organization's activities. The Consumer Satisfaction Index is data and information about the level of customer satisfaction obtained from the results of quantitative and qualitative measurements of customer opinions in obtaining public services by comparing expectations and reality.

According to Iqbal (2008), there are many benefits received by the company by achieving a high level of customer satisfaction. A high level of customer satisfaction can increase customer loyalty and prevent customer turnover, reduce customer sensitivity to prices, reduce marketing failure costs, reduce operating costs caused by increasing the number of customers, increase advertising effectiveness, and improve business rep- 
utation (Iqbal, 2008)

According to Moenir (2008: 27) defining service is a series of activities that take place routinely and continuously covering the entire life of people in society. Based on this understanding service can be interpreted that service is a routine and continuous activity in the community. Furthermore, Sinambela (2008:5) suggests that service is any activity that is profitable in a group or entity and offers satisfaction even though the results are not physically bound to a product. This shows that service is related to the inner satisfaction of the recipient of the service.

According to Ivancevich, Lorenzi, Skinner and Crosby (Ratminto and Winarsih, 2010: 2) "service is products that are visible (cannot be touched) that involve human efforts and use of equipment" Referring to this opinion, service can be interpreted as something that cannot be seen but can be felt which involves human efforts and using an equipment.

Furthermore, from the results of distributing questionnaires given by trainees to the services provided by participants, the results were $44.44 \%$ (four services provided to participants were quite satisfactory), which meant that there was no participant who gave satisfaction to the level of dissatisfaction. The services are 1. Learning facilities, 2. Complaint handling, 3. Desire to use the agency as a place of training, 4 . Willing to recommend the health center as a training place.

The very dissatisfied variable is satisfied with the accommodation service which is equal to $1.90 \%$. Satisfied for satisfied variables, very satisfied, is at the service of teaching and learning activities, which is $43 \%$. And for the satisfaction of the very satisfying level, the service of the participants wanted to recommend the Batam health center as a comfortable training place for friends or colleagues, amounting to $88.50 \%$.

From the overall services provided to participants, the results showed that environmental cleaning services ranked first with a score of $90.90 \%$.

From the description above, it can be concluded that with a clean and comfortable environment, the participants wished to be able to return to other training in Batam Health Center and were willing to recommend to friends or colleagues to use the Batam Health Training Center, like a comfortable and pleasant training place.

According to research conducted by Wowor (2015), that the level of customer satisfaction is influenced by aspects of the product, price, place and overall service provided by the Kartini has reached expectations and even exceeded the expectations of consumers (Wowor, 2015). Satisfaction related to the 5 dimensions of service, as the results of research conducted by Thoblas, et al., Namely tangible, reliability, responsiveness, assurance and empathy to support service quality have a positive effect on customer satisfaction (Sarbunan, Montolalu, Tumble, nd ) who supported Cahyani (2016), that to achieve optimal satisfaction. 


\section{CONCLUSION}

Respondents in the customer satisfaction survey conducted by Bapelkes Batam in the first semester of 2018 were 374 with the largest proportion of Health Promotion Training being 120 people (20.63\%). A total of $44.44 \%$ (4 types of services) which stated the level of satisfaction of dissatisfied levels reached $0.00 \%$. Shows that the customer satisfaction index reaches 0.94 very satisfied, with the highest IKP in learning facilities services and the desire of respondents to recommend Batam Health Agency to friends and colleagues reaching $0.96 \%$ and the lowest service level of teaching and learning activities reaches $0.88 \%$. While the index of community satisfaction reached a value of $70.21 \mathrm{~B}$, the predicate of the performance of service units in the Batam Health Agency is Good. Overall the trainees felt very satisfied. 


\section{REFERENCES}

1. Atmodiwiro, S. (2012). Training Management. Jakarta: Ardzadizya.

2. Cahyani, P. D. (2016). Customer Satisfaction Levels on the Quality of Sharia Banking Services in Yogyakarta. Journal of Business and Management, 6 (2), 151-162.

3. Decree of the Minister of Administrative Reform, Number: KEP/25/M.PAN/ 2/2004, 2004 about General Guidelines for Preparation of the Community Satisfaction Index of Government Agency Service Units.

4. Indriyani, D. (2018). Principles of Total Quality Service. Yogyakarta: Andi Offset.

5. Iqbal, M. (2008). Effects of Perceived Value, Hope, and Trust in Consumer Satisfaction. Journal of Management Research.

6. Kotler, P. (2002). Marketing Management for Asian Perspectives. Yogyakarta: Andi Publisher.

7. LAN RI. (2003). Administration Module for Organizing Education and Training. Jakarta: Institute of Public Administration.

8. LAN RI. (2003). Excellent Service Module in Organizing Diklat. Jakarta: Institute of Public Administration.

9. Law Number 36 of 2009 , n.d. Health

10. Law Number 5 of 2014, n.d. State Civil Apparatus

11. Law Number 25 of 2009, n.d. Public Service

12. Melyanasari, D. (2012). Batam Bapelkes Customer Satisfaction Survey Report in 2012. 1 ed. Batam: Batam.

13. Nasir, M. (1988). Research Methods. Jakarta: Ghalia Indonesia.

14. Permenkes RI Number 2361 / Menkes / Per / XI / 2011, n.d. Organization and Administration of Technical Implementation Units in the Field of Health Training.

15. Suparyanto, J. (2006). Measurement of Customer Satisfaction to Increase Market Share. Jakarta: Rineka Cipta.

16. Thoblas S. Sarbunan, Jhon Montolalu, Tinneke M Tumbel, n.d. Service Quality Analysis of Customer Satisfaction at PT Bank BTPN Kanca Manado.

17. Wowor, M. C. (2015). Klappertaart Consumer Satisfaction Level at Kartini Cake and Bakery Manado. Manado: Manado's Sam Ratulangi University Faculty of Agriculture.

18. Zeithmal, A. Z., Leonard, L. B., \& Parasuraman, A. (2006). Effect of Service Quality on Customer Satisfaction at Ayam Penyet Ria Restaurant. Petra Marketing Management Journal, 1 (2), 1-7. 